\title{
Er faglig veiledning nyttig for sykepleiere?
}

Nyere forskning tyder på at veiledning kan styrke sykepleierne i jobben de gjør, og at veiledningen derved også kommer pasientene, de pårørende og arbeidsgiverne til gode.

Gry Bruland Vråle

Sykepleiefaglig veileder og førstelektor emerita

VID vitenskapelige høgskole, campus Diakonhjemmet

Elin Drangsholt

Intensivsykepleier

Postoperativ og intensivavdelingen, Akuttklinikken, Oslo universitetssykehus, Ullevål

Etikk

Mestring

Veiledning

Arbeidsbelastning

Sykepleien 2020108 (82535) (e-82535)

DOI: 10.4220/Sykepleiens.2020.82535

\section{Hovedbudskap}

Artikkelen presenterer hvordan nyere kvalitativ forskning beskriver betydningen av sykepleiefaglig veiledning. Funnene er inndelt etter veiledningens normative, formative og restorative funksjon. Den normative funksjonen bidrar til å opprettholde god praksis og omsorg. Den formative funksjonen styrker faglig refleksjon og forståelse. Den restorative funksjonen gjenoppretter og styrker sykepleierens iboende kapasitet og kompetanse gjennom støtte og anerkjennelse.

Hvilken betydning kan veiledning ha for sykepleiere? Denne artikkelen gjør rede for og drøfter resultatene fra de kvalitative studiene i en internrapport (1) som Faggruppen for veiledere i Norsk Sykepleierforbund (NSF) har utarbeidet. 
Rapporten, som beskriver kunnskapsgrunnlaget for sykepleiefaglig veiledning ut fra nyere forskning, er drøftet videre i artikkelen Finnes det evidens for at sykepleiefaglig veiledning er nyttig? (2).

I denne artikkelen diskutere vi hvilken betydning veiledning kan ha for sykepleiere og derved også for pasienter, pårørende og arbeidsgiver.

\section{Hva er veiledning?}

Det finnes ingen felles definisjon av hva faglig veiledning er. Faggruppen for veiledere i Norsk Sykepleierforbund beskriver veiledning som en virksomhet som bidrar til at sykepleiere kan bli kjent med seg selv, bearbeide sitt refleksjonsgrunnlag og bevisstgjøre praktiske handlingsvalg (3). Dialog og refleksjon over praksiserfaringer er en sentral arbeidsform i veiledningen (4-6).

\section{Å få veiledning kan være inspirerende}

Fra et ledelses- og organisasjonsnivå kan sykepleiefaglig veiledning bidra til kvalitets- og kompetanseutvikling, godt arbeidsmiljø og inspirerte sykepleiere (3).

Tveiten viser til forskning frem til 2013 og oppsummerer betydningsfull virkning av veiledning slik: «Forebygging av utbrenthet, styrket relasjon mellom yrkesutøvere og pasienter/klienter, ansvarlighet, emosjonell styrke, sensibilitet, $\varnothing \mathrm{kt}$ motivasjon i jobben, $\varnothing \mathrm{kt}$ samarbeidsevne, styrket yrkesidentitet, utvikling av analytiske ferdigheter og vurdering av god praksis, samt utvikling av tverrfaglig samarbeid» (5, s. 23-24).

Denne studien søker svar på problemstillingen: Hvordan beskriver forskningslitteratur betydningen av sykepleiefaglig veiledning i grupper?

\section{Metode}

Studien er en litteraturgjennomgang som bygger på 78 kvalitative studier fra et litteraturs $\varnothing \mathrm{k}$ i forbindelse med internrapporten (1). Søket er avgrenset til engelskspråklige og skandinaviske studier om sykepleiefaglig gruppeveiledning.

Søket ble foretatt i databasene Medline, Cinahl og SweMed+ samt utvalgte referanselister publisert fra 2008 til 2017.

Søkeord var clinical supervision, group process, group, mentoring, nurse, nursing staff, nursing supervisory, peer group, professional competence. 
Søkene ga 189 treff. Studier som omhandlet studentveiledning og individuell veiledning, ble ekskludert. Etter gjennomlesing av alle abstrakter, ble fire oversiktsartikler og sju primærstudier inkludert i rapporten (2). De fire oversiktsartiklene er publisert i en egen artikkel (4).

De sju primærstudiene gir utdypende kunnskap om betydningen av sykepleiefaglig veiledning i grupper. Primærstudiene er denne artikkelens datagrunnlag. De er alle fra nordiske land.

\section{Resultater}

Sentrale funn i hver av de sju studiene ble lagt inn i tabeller og sortert i tre funksjoner etter Proctor (7) sin modell: en normativ, en formativ og en restorativ (styrkende) funksjon av sykepleiefaglig veiledning.

\section{Normativ funksjon beskriver hvordan noe bør være}

Normativ er en beskrivelse av hvordan noe bør være. Den normative funksjonen i sykepleieveiledningen er retningsgivende og peker på hva som er rett og riktig utøvelse av faget. Dette kan knyttes til sykepleiernes identitet, moralske dømmekraft og faglige forståelse.

Studiene beskriver at veiledningen styrker den faglige identiteten (8), og bevisstheten om verdigrunnlaget (9). Moralsk støtte fra kolleger kan også styrke den profesjonelle forpliktelsen (10).

\section{$\equiv \ll$ Moralsk støtte fra kolleger kan styrke den profesjonelle forpliktelsen.»}

Flere av studiene (9-11) knytter betydningen av veiledning til verdier og etikk, og bruker ord som moralsk sensitivitet (10), bevisstgjøring av egne verdier, tydeliggjøring av etiske omsorgsverdier og moralsk ansvar og mot i praksis (9). Et utsagn i denne studien (9) er: «Å konkretisere etiske dilemmaer kan bidra til å påvirke systemet - systemverden. Veiledningen har gitt mot.»

Videre kan veiledning gi $\varnothing \mathrm{kt}$ innsikt og forståelse for det å beholde empati, forpliktelse og medmenneskelighet i profesjonell omsorg (10). 
En studie (10) viser til at veiledning har en positiv effekt på sykepleieres verdier, holdninger og væremåter i møte og samarbeid med pasienter. En studie (11) viser til høyere jobbtilfredshet. En studie (12) viser til økt kvalitet på det daglige arbeidet.

\section{Formativ funksjon handler om å forme og forandre}

Den formative funksjonen i veiledning viser til hvordan veiledning kan forme og forandre sykepleieren gjennom utvikling og kompetanseheving.

Erfarings- og kunnskapsutveksling i en veiledningsgruppe kan gi nye perspektiver på sykepleiernes praksis og utvide deres handlingsrom.

\section{$\equiv$ «Deltakerne i en gruppe kan både støtte og utfordre hverandre.»}

Deltakerne i en gruppe kan både støtte og utfordre hverandre.

Slik økes den faglige kompetansen.

I en studie (13) beskrives veiledning som en ledet refleksjon, der deltakerne deler hverandres innsikter, og det oppstår en følelsesmessig lettelse når de andre deltakerne lytter, gjenkjenner og anerkjenner problemet. Slik kan deltakernes profesjonelle kompetanse og profesjonelle selvfølelse styrkes.

Erfaringsutvekslingen kommer særlig de minst erfarne til gode (10). Betydningen av erfaringsutveksling knyttes i en studie (12) til oppdagelsen av at mestring i fellesskap med andre kan lede til kunnskapsinnhenting, styrket evne til å si fra, søke støtte samt øve på og utvikle nye ferdigheter.

\section{Refleksjon øker bevisstheten om handlingsvalg}

Veiledning kan bidra til at en sykepleier får dypere forståelse for hvordan han eller hun påvirker pasientrelasjoner (10). Refleksjon over egen praksisut øvelse $\varnothing$ ker bevissthet om handlingsvalg (9), og gir selvtillit og selvstendighet hos sykepleiere $(8,12,14)$. Refleksjoner i veiledning kan styrke selvstendighet i praksis (11).

Veiledning kan også bidra til selvrefleksjon og økt selvinnsikt om hvordan en håndterer emosjonelle kriser og reaksjoner (10). Det vises også til økt kvalitet i oppmerksomt nærvær (12), bedre lytteevne og kommunikasjonsferdighet, mer respekt og vilje til å la andre få ordet (10). 


\section{Restorativ funksjon handler om å styrke sykepleiere}

Den restorative funksjonen viser til hvordan veiledning kan bidra til å gjenoppbygge og styrke sykepleiere. Veiledningens styrkende funksjon er her systematisert ved punktene:

bekreftelse, deling og mestring.

Bekreftelse bidrar til stressreduksjon (8) ved at sykepleierne som får veiledning, kan lufte ut og motta anerkjennende bekreftelse (13).

\section{A dele kan lette på trykket}

Metaforen sikkerhetsventil (10) brukes for å beskrive hvordan deling av erfaringer i veiledning kan lette på trykk som oppstår ved håndtering av vanskelige situasjoner. Veiledning kan være et rom for å dele og avklare moralsk ansvar og etterleve sin forpliktelse (9).

\section{三 «Veiledning kan lette på emosjonelle belastninger og gi trøst i arbeidet.»}

En av studiene (13) viser til at noen kan føle et ubehag og utrygghet ved å fortelle om vanskelige situasjoner for kolleger dersom veiledningen ikke er godt innrammet, trygg og forutsigbar. Deltakerne i denne studien fant likevel at veiledning kan lette på emosjonelle belastninger og gi trøst i arbeidet.

Deling av positive tilbakemeldinger knyttes til høyere grad av indre motivasjon (11).

\section{Kollegastøtte kan føre til bedre jobbmestring}

Kollegast $\varnothing$ tte i veiledning kan, ifølge en studie (10), gi sykepleierne bedre jobbmestring, økt engasjement og et bedre samarbeid med kolleger, noe som gir en mer positiv holdning i det daglige arbeidet.

En studie (11) viser til økt opplevelse av kontroll og selvstendighet i det daglige arbeidet, samt $\varnothing \mathrm{kt}$ forpliktelse og positivitet til utfordringer. En studie (14) viser at veiledning kan øke sykepleiernes evne til å håndtere stress. 


\section{Diskusjon}

Siden studiene i utvalget i all hovedsak ser på hva sykepleiefaglig veiledning kan bety for sykepleierne både individuelt og i gruppe, vil diskusjonen i all hovedsak handle om det.

Betydningen av veiledning for de ulike bruker- og pasientgruppene og samarbeidspartnerne som sykepleierne møter i det daglige, sier studiene i utvalget vårt lite om. Vi vil likevel også drøfte hvilken betydning veiledningen trolig har for samarbeidspartnere som pasienter, pårørende og kolleger.

\section{Betydningen av veiledning for sykepleiere}

Deling og felles refleksjon over reelle praksissituasjoner ser ut til å skape et betydningsfullt profesjonelt fellesskap for utøvende sykepleiere.

Deling og felles refleksjoner kan motvirke noe av den ensomheten som kan oppstå når man er alene om viktige beslutninger, i en fortløpende og hektisk praksishverdag.

\section{三 «Deling og felles refleksjoner kan motvirke noe av den ensomheten som kan oppstå når man er alene om viktige beslutninger.»}

Ensomheten kan også forstås ut fra praksishverdagens

mange, sammensatte og krevende instrumentelle og relasjonelle oppgaver. Praktiske prosedyrer og behandlingsmetoder kan kreve fasthet og fleksibilitet på en gang når det skjer i en relasjon til pasienter, pårørende og andre samarbeidspartnere.

Viktige moralske spørsmål og valg må ofte gjøres raskt og effektivt uten tid til nødvendige overveielser. I en veiledningskontekst får sykepleierne anledning til å både tenke over det som skjedde og det som ikke skjedde (15).

Veiledning kan på sitt beste være et raust rom der sykepleierne kan diskutere både hvordan verdier kommer til uttrykk i praksis, og hvordan det stemmer med både egne profesjonsverdier og organisasjonsverdier (16). I slike diskusjoner kan justeringer og nyvinninger for praksis skapes. 
I en veiledningssituasjon kan sykepleierne få tid og anledning til etiske refleksjoner der både faglige og personlige verdier og dømmekraft blir satt ord på og delt (17). Dømmekraft forutsetter både evne og tid til å få øye på det moralsk betydningsfulle i en situasjon, å gjøre en kritisk refleksjon over sin iakttakelse og å ta dømmekraften i bruk ved å velge god og riktig handling (17, s: 27).

\section{Fellesskapet kan motvirke slitasje}

Både fellesskapet og det at tempoet er langsommere (18) i en veiledning enn i det daglige praktiske arbeidet, er trolig en nødvendig motkraft til slitasje og en forutsetning for at kvalitetsutvikling og kvalitetssikring skal kunne skje.

Den normative, formative og styrkende funksjonen av veiledning kan beskrives atskilt slik vi gjør det i resultatdelen. Den mest betydningsfulle funksjonen av veiledning finner vi mest sannsynlig i summen av de tre funksjonene, mer enn $\mathrm{i}$ hver enkelt av dem.

\section{Betydningen for pasienter, pårørende og arbeidsgivere}

Sykepleiere som er moralsk sensitive og ansvarlige og som har en sterk faglig kompetanse og profesjonell bevissthet, er avgjørende for så vel omsorgen og behandlingen, som for arbeidsstedets omdømme.

I vår studie har vi bare sykepleiernes egne ord for at de ved å delta i sykepleiefaglig veiledning har utviklet de egenskapene som er nevnt ovenfor.

\section{Veiledningen kommer andre til gode}

Vi vil anta at det er den styrkende funksjonen i veiledningen som gjør at sykepleierne utvikler en faglig og moralsk bevissthet, som kommer pasienter og pårørende samt arbeidsgivere til gode. Vår antakelse st $\varnothing t t e s ~ a v$ forskningsresultater som også tyder på at den styrkende funksjonen i veiledningen bidrar til faglig og moralsk bevissthet (19-20). 
Noen aspekter ved arbeidet som sykepleier kan medføre både smerte og ubehag. Det kan være når sykepleiere opplever uløselige etiske dilemmaer, der uansett hvilken beslutning de tar, vil det føre til at pasienten blir krenket eller påført smerte. Det kan være når vi berøres så sterkt i møte med pasienter, at vi selv trenger trøst og lindring i et kollegialt veiledningsfellesskap (6).

Vi mener at det er grunn til å tro at når sykepleiere trives og har faglig bevissthet og styrke kommer det pasienter og pårørende til gode. For pasienter kan det være særlig godt å møte sykepleiere som har integritet og mot nok til å tilpasse omsorgen ut fra den enkeltes behov.

\section{En sterk stab kan bidra til lavere sykefravær}

For arbeidsgivere vil en sterk sykepleiestab trolig medføre lavere sykefravær og mindre utskifting i staben. Det kan bidra til god kontinuitet i en organisasjon.

Veiledning kan stimulere sykepleieres faglige refleksjoner og ved det forbedre arbeidsklimaet mellom kolleger, gi ø $\varnothing \mathrm{kt}$ jobbmotivasjon og engasjement. Det kommer både arbeidsgivere og pasienter til gode.

En viktig forutsetning for et betydningsfullt, konstruktivt og virksomt veiledningstilbud er at veiledningen er tilpasset den faglige konteksten som sykepleierne arbeider i til daglig (20).

\section{Metoderefleksjon}

Utvalget består av fagfellevurderte artikler fra de senere års forskning. Flere av artiklene (8-10), er skrevet av forskere som også var veiledere for deltakerne. Det kan gi en skjevhet/bias i noen av studiene i utvalget.

Datautvalget kan trolig også kritiseres fordi det skriver seg fra til dels svært ulike kontekster, av ulike veiledere som bruker forskjellige metoder og sykepleiere med svært ulik erfaringsbakgrunn. En kritikk som kan knyttes til studiens analyse, er at en metaanalyse og kan åpne for feiltolkninger (21).

\section{Styrker ved studien}

Analysen er gjort av de to forfatterne dels hver for seg og dels sammen, noe som kan betraktes som en styrke. 
En annen styrke kan være at resultatene i stor grad bekrefter tidligere studier og kunnskap som er omtalt i fagbøker om veiledning (4-6).

Det er også en styrke at studiene har mange sammenfallende resultater, til tross for at studiene er gjort i ulike land, av grupper av sykepleiere med ulike fagområder og at det trolig er brukt ulike veiledningsmetoder.

\section{Konklusjon}

Veiledningens restorative funksjon gjenoppretter og styrker sykepleierens iboende kapasitet og kompetanse gjennom støtte og anerkjennelse.

Den normative funksjonen bidrar til å opprettholde god praksis og omsorg ved at sykepleiere får ærlige, kritiske og konstruktive tilbakemeldinger når de reflekterer over aktuelle praksissituasjoner.

Den formative funksjonen styrker faglig refleksjon og forståelse og bidrar til læring og praktisk dyktighet.

\section{Referanser}

1. Drangsholt E, Saxlund AM, Vråle GB. Det forskningsbaserte kunnskapsgrunnlaget i sykepleiefaglig veiledning - en litteraturgjennomgang. En internrapport. Upublisert; 2018.

2. Drangsholt E, Vråle GB, Saxlund AM. Finnes det evidens for at sykepleiefaglig veiledning er nyttig? Sykepleien: 2019. DOI: 10.4220/Sykepleiens.2019.77672

3. Norsk Sykepleierforbund. NSFs faggruppe for veiledere. Veilederen. Om faglig veiledning i sykepleie. Tilgjengelig fra: http://digiblad.no/nsf/veilederen/ (nedlastet 06.03.20).

4. Teslo AL. Veiledning - definisjoner og utvikling. I: Teslo AL, red. Mangfold i faglig veiledning for helse- og sosialarbeidere. Oslo: Universitetsforlaget; 2006. s. 19-28.

5. Tveiten S. Veiledning - mer enn ord. 4. utg. Bergen: Fagbokforlaget; 2013.

6. Vråle GB. Veiledning når det røyner på ... Oslo:

Gyldendal akademisk; 2015. 
7. Proctor B. Training for the supervision alliance. I:

Cutcliffe, JR, Hyrkäs K, Fowler J, red. Routledge Handbook of Clinical Supervision, Fundamental International Themes.

New York: Routledge; 2011. s. 23-33.

8. Nordbøe CE, Engmarker I. The benefits of personcentered clinical supervision in municipal health care employees` experiences. Open Journal of Nursing. 2017(7):548-60.

9. Vråle GB, Borge L, Nedberg K. Etisk refleksjon og bevisstgjøring i veiledning. Sykepleien: 2017. DOI: Sykepleien.no/ Forskning 10.4220/Sykepleienf.2017.61626

10. Brink P, Bäck-Petterson S, Senert N. Group supervision as a means of developing professional competence within pre-hospital care. International Emergency Nursing. 2012;20:76-82.

11. Koivu A, Saarinen PI, Hyrkas K. Who benefits from clinical supervision and how? The association between clinical supervision and the work related wellbeing of female hospital nurses. Journal of Clinical Nursing. Sep. 2012;21(1718):2567-78.

12. Hoffart RAR, Larsen SH, Røe KI. Hjelper utbrente sykepleiere. Sykepleien: 2014 .

DOI: 10.4220/sykepleiens.2014.0015

13. Buus N, Angel S, Traynor M, Gonge H. Psychiatric hospital nursing staff's experiences of participating in groupbased clinical supervision: A interview study. International Journal of Mental Health Nursing. 2011;20:95-101.

14. Dawber C, O'Brien TA. Longitudinal, comparative evaluation of reflective practice groups for nurses working in intensive care and oncology. Journal of Nursing and Care. 2013;2(3):138

15. Bergren I. Etisk undran i omvårdnadshandledning. I: Lasseius E, Severinsson E, red. Hermeneutik i vårdpraxis. Det nära, det flyktiga, det dolda. Malmø: Gleerups; 2014. s. 177-86.

16. Askeland H, Aadland E. Hva er verdier, og hva tjener de til? I: Aadland E. Askeland H. Verdibevisst ledelse. Oslo: Cappelen Damm Akademisk; 2017. s. 26-49. 
17. Aakre M. Jakten på dømmekraft. Praksisnært etikkarbeid i Helsetjenesten. Oslo: Gyldendal akademisk; 2016.

18. Kahneman D. Tenke fort og langsomt. Oslo: Pax forlag; 2013.

19. Brunero S, Stein-Parbury J. The effectiveness of clinical supervision in nursing; an evidenced based literature review. Australian Journal of Advanced Nursing. 2008:25(3); 86-94.

20. Dilworth S, Higgins I, Parker V, Kelly B, Turnes J. Finding a way forward: A literature review om current debates around clinical supervision. Contemporary Nurse. 2013;45:22-32.

21. Malterud K. Kvalitative metoder i medisinsk forskning. En innføring. Oslo: Universitetsforlaget; 2017. 